\title{
Bad Samaritans, Aftertastes, and the Problem of Evil
}

\author{
Eugene Schlossberger
}

Received: 8 December 2013 / Revised: 9 May 2014 / Accepted: 31 October 2014 /

Published online: 21 November 2014

(C) The Author(s) 2014. This article is published with open access at Springerlink.com

\begin{abstract}
The paper argues first that, by not rescuing innocents in certain ways (e.g., deflecting the path of bullets), God violates a weak Bad Samaritan principle that few would deny. This 'Bad Samaritan argument' appears to block the traditional free will defense to the problem of evil, since respecting the principle does not violate or show lack of respect for free will. Second, the paper articulates a version of the traditional argument from evil, the 'Aftertaste argument', that appears to close some of the traditional loopholes in the argument from evil, such as the 'greater good from evil' defense.
\end{abstract}

Keywords Argument from evil $\cdot$ Free will $\cdot$ Existence of God

Two arguments concerning the problem of evil points deserve attention: the 'Bad Samaritan problem,' which is not only an argument in its own right but also appears to defeat the traditional free will defense to the problem of evil, and the 'aftertaste argument.' Taken together, the two arguments present a formidable challenge to belief in an omnipotent and beneficent God.

\section{The Bad Samaritan Argument}

The Bad Samaritan problem arises from questions about the duty to rescue. Controversy exists concerning the moral status of averting harm and of rescuing those to whom one does not have a contractual or fiduciary duty. Several jurisdictions in the United States, France, Germany, and Belgium have enacted Bad Samaritan laws imposing a duty to assist (Silver 1985 and Holland 1967). Off-duty, licensed healthcare professionals who fail to respond to an emergency are subject to sanctions in some jurisdictions. The topic has also received significant philosophical attention (see, for example, Malm 1995). Peter Singer famously wrote:

E. Schlossberger $(\bowtie)$

Department of English and Philosophy, Purdue University Calumet, Hammond, IN 46321, USA

e-mail: esschlos@purduecal.edu 
If it is in our power to prevent something bad from happening, without thereby sacrificing anything of comparable moral importance, we ought, morally, to do it. (Singer 1972: 231).

Bernard Gert (1970) denies that beneficence is a duty, but allows that beneficence is a moral ideal. Consequently, Gert would not deny that, even concerning harms to innocent others one did not cause, beneficence is morally preferable to indifference. Someone who displays such indifference is less morally lustrous than someone equally punctilious about obligation who also acts beneficently on appropriate occasions. Thus few would strongly object to what may be called 'the weak Samaritan principle':

WSP: It is a moral shortcoming (it is morally less than ideal) not to rescue from serious harm or avert serious harm to an innocent other when a) it is within one's power to do so, b) without significant, non-tangential cost or risk to oneself or to the innocent pursuits of others, and c) without doing a wrong or violating a right.

Clause b) requires some explication. WSP is silent about averting harms at the cost of setting back someone's non-innocent pursuits, e.g., setting back a murderer's interest in the death of his intended victim. Nonetheless, almost any action may set back someone's innocent interest. For example, by saving A's uncle's life, B may stall or prevent A's inheriting money from her uncle's will that would allow her to continue her medical research. The phrase 'non-tangential' is intended to cover such cases. On the other hand, should aliens threaten to destroy the planet if Smith is not harmed, it is (in the eyes of most) not a moral shortcoming to refrain from averting harm to Smith. Furthermore, a zealous act utilitarian might insist that tangential utility be given full and equal consideration. Such objections, including Trolley considerations about using one person to serve the needs of many, are answered by clause c). Knowingly allowing the planet to be destroyed by averting harm to Smith would, presumably, be acting wrongly. A zealous act-utilitarian would hold that saving A's uncle at the cost of forestalling a cure for cancer is acting wrongly.

Note that if I, acting in accordance with WSP, push an innocent victim, A, out of the path of the bullet coming from the gun of an attempted assassin, B, or activate a metaldeflecting device that changes the path of the bullet (in a way that does not pose a risk to others), I cannot be said to fail to respect the assassin's free will. B made his choice without any interference by me. He acted in pulling the trigger without any interference from me. Only after he acted did I interfere with the outcome of his action. I did so without acting wrongly or violating B's rights. Even if B has a right not to be pushed, he does not have an entitlement claim on me not to push his intended victim or not to divert the path of his bullet. Similarly, I neither violate a poisoner's rights nor disrespect his free will if I neutralize the poison he introduced into his prospective victim's cup.

The relevant point is that WSP would apply to a God powerful enough to divert the path of the bullet to a safe target. There have been many actual instances of an assassin unjustifiably killing an innocent victim. In many of those cases, a moderately powerful God would have been able to save the victim from the assassin's attack, without keeping the assassin from choosing and acting freely (exercising his free will), in a way that poses no serious harm or risk to innocent others, and without doing a wrong or violating a right. Thus, if such a God exists, She is a bad Samaritan, morally blemished. 
The Bad Samaritan problem seems to obviate the traditional free will defense to the problem of evil. Respecting free will does not entail refusing to rescue an innocent person from the natural outcome of the exercise of free will. Respecting free will might entail that God refrain from interfering with B's choice to pull the trigger. It might require that God not stop B from pulling the trigger. It cannot mean refusing to change the course of the bullet after B has finished performing his action. It might be suggested that, if God routinely averted evil, people would become discouraged from attempting to perform evil, thereby exerting a chilling effect on the exercise of free will. However, let $\mathrm{N}$ represent the present number of thwarted attempts, worldwide, at performing actions that unjustifiably harm innocent others. No one could reasonably insist that increasing $\mathrm{N}$ by one would have a significant effect on the free exercise of the will. Thus there is room for God to be a better Samaritan than She is, that is, violate WSP less often, without significantly affecting the exercise of free will. (For a further objection to this reply, see section iii.)

Of course, it might be argued that God does not save A from the bullet because greater good emerges from A's death. However, if that is the reason God does not rescue $\mathrm{A}$, the fact that $\mathrm{B}$ possesses free will is irrelevant. What remains is a version of the 'greater good' defense (that God permits evils to exist because they give rise to greater goods).

\section{The Aftertaste Argument}

The greater good defense, in turn, appears unable to explain a variant of the traditional argument from evil. Traditional expositions of the argument from evil focus on comparing actuality against the imagined elimination of a large evil or against the imagined addition of a large benefit. The 'aftertaste argument', as I shall call it, focuses on a tiny improvement to the actual world. Consider some instance in the actual world, W, in which a person, $\mathrm{P}$, ate a mint. The initial pleasant taste of the mint gave way, at time $\mathrm{T}$, to an unpleasant aftertaste. Now consider possible world W1, in which P (or P's counterpart), as the result of a tiny miracle, M1, experiences the unpleasant aftertaste a fraction of a second later, at T1. At T2, a further fraction of a second later, a second tiny miracle, M2, occurs. The second tiny miracle makes whatever physical changes are necessary to make $\mathrm{W}$ and $\mathrm{W} 1$ indiscernible at time T2. As a result, W and W1 are indiscernible after T2. In other words, $\mathrm{W}$ and $\mathrm{W} 1$ differ only between $\mathrm{T} 1$ and $\mathrm{T} 2$. Note that M1 and M2 are both miniscule, affecting only a relatively small number of molecules and/or electron states in P's brain.

Now, if God is omnipotent, She could certainly have created W1 instead of W. If God is benevolent, She would prefer W1 to W, since the only difference is the substitution, in the experience of one person, of a brief period of minor pleasantness for a brief period of minor unpleasantness. But, since W is, ex hypothesi, the real world, God created W instead of W1. Thus God is either not omnipotent or not beneficent. ${ }^{1}$

Two possible responses to the aftertaste argument remain to be explored. One response suggests that perhaps $\mathrm{W} 1$ is, in fact, the world in which we find ourselves. After all, M2 would eliminate any knowledge of M1. However, suppose that such

\footnotetext{
${ }^{1}$ Roger Crisp (1986) points out that a less than omnipotent God might still be worthy of worship, but it seems dubious that a God worthy of worship would be unable to effect two such tiny miracles.
} 
miracles in fact occurred in the real world. Let $\mathrm{n}$ be the length of time between $\mathrm{T} 1$ and T2. Then there is a world, W2, which is exactly similar to our world except that M2 occurred at time T3, a fraction of a second later than T2. In other words, unless $n$ is infinitely long, there is always another world $\mathrm{W}^{*}$, otherwise just like the real world, in which $\mathrm{n}$ is marginally longer, such that, were God both omnipotent and benevolent, God would have created $\mathrm{W}^{*}$ rather than the real world.

Alternatively, it could be argued that the real world is better than W1, either because a) the real world is perfectly just while W1 is marginally unjust (since P escapes a tiny amount of deserved unpleasantness) or because b) the small gain in pleasure does not outweigh the loss in perfection occasioned by violation of causal law. The perfect justice response is implausible. Indeed, if the claim that the world is perfectly just were at all plausible, there would be no need for either the free will or the greater good defenses. Claims concerning the perfection of causal law raise several complex issues, but it should be noted that many religions for which the problem of evil arises posit the occurrence of miraculous violations of causal law that are taken to be evidence of God's greatness, not of imperfection.

A theist might reply that, despite the apparent force of the aftertaste argument, human beings are simply not in an epistemological position to judge the overall goodness of states of affairs. Stephen Wykstra (1984) suggests our moral understanding might compare to that of an omniscient deity's as a 1 month old infant's does to its parent's. Since a neonate, unlike a normal adult, lacks both any sense of good or evil as well as any means by which to communicate about such matters, a more apt comparison might be an ordinary two-year-old versus Kant or Aristotle. If that is correct, however, the 'bad parent' argument arises. While a 2 year old may not be able to understand the categorical imperative, a parent whose treatment of the two-year-old is utterly morally incomprehensible to the 2 year old is simply a bad parent. By appearing to act arbitrarily and unjustly, a parent sets a bad example for the child and leads the child to regard injustice as the norm. Parents should strive to make their treatment of their child at least minimally intelligible within a two-year-old's limited moral compass and, when not feasible, reassure the two-year-old that a good reason exists, offering a promissory note for a later explanation. Hence, if God exists, She is a bad parent.

Theists, of course, might reply that we are not in a position to know God's reasons for being a bad parent. However, skeptical theism, whether about God's reasons for being a bad parent or about the nature of the goods involved in the Aftertaste argument, does not seem plausible. Given the very limited parameters of the aftertaste argument, there seems little room for doubt that W1 is preferable to W. Moreover, adopting this kind of broad skeptical theism "undermines our ability to engage in perfectly ordinary kinds of moral reasoning" (Almeida and Oppy 2003, 511). Because it entails that we can never properly judge whether any given action produces overall moral good or evil, "applying the skeptical theist's position to the logical problem of natural evil leads to complete moral agnosticism" (Johnson 2012, 9).

\section{The No Best World Defense}

Two related final issues must be addressed. A theist might argue, following (Adams 1972), that God is not obligated to create the best possible world. Alternatively or additionally, as noted by an anonymous referee, a theist might reply to the aftertaste 
argument as follows: if, no matter how long God delays the bitter aftertaste, there is always a better world in which God delayed the bitter aftertaste a microsecond longer, then there is no best world with respect to delaying the aftertaste. But, as Robert Adams put it, "if there is no maximum degree of perfection among possible worlds, it would be unreasonable to blame God, or think less highly of his goodness, because he created a world less excellent than he could have created' (Adams 1972, 317). Similarly, theists might object to the Bad Samaritan argument that no matter how many bullets directed at innocent victims God deflected, God could always deflect one more bullet without undermining murderers' confidence in their choices enough to undermine the exercise of free will. But, if there is no optimal number of bullets to deflect, God cannot be blamed for not deflecting the optimal number.

Because a large literature surrounds these questions, it is sufficient here to indicate a number of lines along which a reply could be made.

Much discussion of whether God is obligated to create the best possible world, given that one exists, rests on cases akin to Adams' example of parents who knowingly took a drug expressly to create mental deficiencies in their child in utero, with the intent of experiencing the joy of giving love to an impaired child and watching that child live up to his or her (diminished) potential. The parents clearly acted wrongly. Yet, in choosing to create deficient creatures such as we are, would not God be acting similarly? Adams' solution is to hold that the parents acted wrongly because they purposely created an offspring 'notably deficient, by comparison with normal human beings, in mental or physical capacity,' and that doing so is wrong because it contravenes God's 'intentions about the qualities and goals of human life' (330). By contrast, God's creation of human beings does not clash with Her own intentions. Hence, the case of the parents does not show, Adams claims, that a morally perfect being would create the best world She could create (assuming such a world exists). Adams' solution, however, is unsatisfactory. If the wrongness of the parents' action consists solely in acting against 'the purposes of God for human beings,' (331) it follows that their action would not be wrong if God either did not exist or did not have specific purposes for human beings. But it seems clear that the parents' action remains morally deficient even if it transpires that Deism is correct. Thus the wrongness of the parent's actions cannot consist solely in contravening God's purposes for human beings.

The case becomes yet stronger when one realizes that the relevant question is not whether God is obligated to create the best possible world She can, but rather whether a morally perfect being would (whether obligated or not) create the best world She is able to create. As Rowe notes, 'creating the best world may be a supererogatory act, the morally best act he can do, even if his failure to do it would not be a violation of his moral duty. And it appears to be inconceivable that a supremely perfect being would act to bring about less good than he can.' (Rowe 2007, 288.) The question, thus, is whether a morally perfect being (not just a morally blameless being) would act as the parents acted. As a result, several cases in which human beings undeniably act differently than a morally perfect being would act, precisely because they deliberately create a worse state of affairs than they could have created, establish a rebuttable presumption that God is less than morally perfect if She creates a worse world than She could have created. The onus is now on the theist to show otherwise.

The above discussion assumes that a best possible creatable world exists. What if no such world exists? William Rowe suggests that, while God might not be blameworthy 
for failing to create the best possible world if there is none, "A being who creates a world when it could have created a better world is less than morally perfect. And the plain fact is that if there is no best creatable world then God, if he creates a world, will create a world than which he could have created a better world' (Rowe 2007, 295). In short, as (Rowe 2004) meticulously argues, if there cannot be a perfectly best world, then there cannot be a perfect being, since one could always conceive of a being greater than the one who (purportedly) created the actual world, namely, a being who created one of the (infinitely many) better worlds. Hence, if God is defined as a perfect being, God does not exist. Similarly, if God is defined as that than which nothing greater can be conceived, and if, for any $\mathrm{x}$, it is always possible to conceive of an $\mathrm{x}^{*}$ which is greater than $\mathrm{x}$, then there can be no $\mathrm{x}$ identical to God. As Rowe points out, the question is whether the concept of a morally perfect being is tenable. If the concept of a morally unsurpassable world is untenable, it would appear that the concept of a morally unsurpassable creator of worlds is also untenable. If, as the Aftertaste argument appears to imply, there is no best possible world, then there is also no morally perfect creator. Similarly, if there is no perfect balance between saving lives (not being a Bad Samaritan) and not undermining free will, then there is no morally perfect creator.

A second line of reply is the 'not even close' rejoinder, which applies to both the Bad Samaritan and Aftertaste arguments. In the Bad Samaritan case, the problem of determining the precise number of bullets, $\mathrm{O}$, deflectable without undermining confidence in free will is akin to the sorites problem. While some numbers of deflected bullets would severely undermine confidence and some numbers would clearly have little effect, there is a range within which confidence is non-trivially lessened, although there may be neither a precise curve of values nor an exactly optimal trade-off between confidence in free will and saving lives. It seems clear, however, that the actual world is not even close to the indeterminate region (particularly as bullets are but one type of example). Were it morally important both to remove grains of sand from a pile and to maintain a heap, the fact that there may be no clear answer to the question of how many grains of sand I may remove before the pile ceases to be a heap does not justifying me in refusing to remove sand from a pile of sand a mile high. Since I can remove many grains before the question of maintaining a heap poses a danger, I ought to begin removing sand. Similarly, God ought to deflect many bullets currently striking innocent victims before the question of undermining confidence in free will poses a danger. Similarly, let us suppose that, however hard I try, I could always have found it within myself to have tried a bit harder. This fact does not justify my making only a cursory effort: I should at least make a strong effort. For the same reason, even if, however good a world God created, She could always have created a better one, creating the actual world, with its blatant inadequacies, does not count as making an adequate effort. Thus, even if God is not blameworthy for failing to create the best possible world or achieve the best possible balance, God is not morally perfect, since She could have done better than She did.

The 'not even close' response applies as well to those versions of the 'multiverse' solution to the no best world problem that maintain that God is unsurpassable if she creates all worlds that are sufficiently good. Since the number of bullet deflected in the actual world is not even close to the optimal number, $\mathrm{O}$, the actual world would appear not to be a sufficiently good world. Some have suggested a minimalist criterion for being sufficiently good. A universe, John McHarry (1978) suggests, is sufficiently 
good if it is better than nothing at all. Donald Turner (2003) considers it sufficient that the world posseses more good than evil. Klaas Kraay suggests that a morally unsurpassable being will create every world 'worth creating,' which he defines as having 'an axiological status that surpasses some objective threshold t' (Kraay 2010, 361). It seems implausible that t be a minimal standard. Even Paul Draper's suggestion (2004) that creating good but flawed worlds increases excellence does not obviously appear to justify copious amounts of needless suffering. Surely the appropriate measure is good minus evil, not quantity of good regardless of evil. Bradley Monton (2010) presents criticisms of several such standards. David Kyle Johnson (2014) argues that there is no best multiverse. In any case, it is not clear that a morally unsurpassable being would create a world in which She was a Bad Samaritan (violated WSP). It is at least a rebuttable presumption that a creator who did not violate WSP would be morally superior.

\section{Logical v. Evidential Arguments from Evil}

William L. Rowe famously distinguished between the logical and evidential arguments from evil, which conclude that the evil present in the actual world demonstrates, respectively, that it is impossible or unlikely that a morally perfect (or morally unsurpassable or omnipotent and perfectly benevolent) being exists. The Bad Samaritan and Aftertaste arguments are presented above as logical arguments from evil, but these logical arguments from evil are, at least secondarily, intended as evidential arguments. For example, Peter van Inwagen suggested in correspondence that (van Inwagen 2006) provides a 'just-so story' making logically consistent the claims that God violates WSP and that God is morally unsurpassable: Adam's fall removed humanity's preternatural powers, thus making us vulnerable to random evils. While God prevents some of these, preventing all of them would make us content with our situation and thus unwilling to participate in the "rescue operation" God has constructed. Even if Van Inwagen is correct, however, that 'just-so story' is unlikely to be true. Thus the Bad Samaritan argument is, at worst, an evidential argument.

Both arguments are presented above in, as it were, their pristine form as logical arguments from evil. Perhaps it is possible to find some way of reconciling the premises of the Bad Samaritan and Aftertaste arguments with the possibility of a morally unsurpassable creator. Perhaps, for example, a theist might reply to the 'not even close' rejoinder by insisting that, in every aftertaste-type case in the actual world, God in fact does create tiny miracles extending the pleasurable taste reasonably close to the optimal amount of time. But that is an unlikely hypothesis to which a reasonable theist would not wish to be bound. Unless the proposed method of reconciliation is at least as plausible and likely as the nonexistence of a morally unsurpassable creator, the two arguments stand as evidential arguments from evil.

\section{Conclusion}

The two arguments presented in this paper both sharpen the argument from evil and block two of the most common lines of defense. Because the Aftertaste argument includes a second tiny miracle that eliminates any future consequences of the first 
miracle, the world after the postulated tiny improvement is exactly the same as the actual world. Thus the Aftertaste argument eliminates the possibility that the evil that we see might result in goods beyond our view or comprehension. The free will defense is not available against the Bad Samaritan argument, since, to adhere to WSP in the manner suggested, God would not need to violate or interfere with free will. Yet, if there is an omnipotent God, She violates WSP. Thus the Bad Samaritan argument shows that if there is an omnipotent God, She fails to meet even the minimal moral expectations we place on human beings, a standard that most human beings actually meet. An omnipotent God, thus, would be morally inferior to even the average human being.

Acknowledgments I wish to thank Peter van Inwagen and the anonymous referees for their extremely helpful comments.

Open Access This article is distributed under the terms of the Creative Commons Attribution License which permits any use, distribution, and reproduction in any medium, provided the original author(s) and the source are credited.

\section{References}

Adams, R. M. (1972). Must god create the best? Philosophical Review, 83(3), 317-332.

Almeida, M., \& Oppy, G. (2003). Sceptical theism and evidential arguments from evil. Australasian Journal of Philosophy, 81(4), 496-516.

Crisp, R. (1986). The avoidance of the problem of evil: a reply to McGrath. Analysis, 46(3), 160.

Draper, P. (2004). Cosmic fine-tuning and terrestrial suffering: parallel problems for naturalism and theism. American Philosophical Quarterly, 41, 311-321.

Gert, B. (1970). The moral rules. New York: Harper and Rowe.

Holland, L. (1967). The good Samaritan laws: a re-appraisal. Journal of Public Law, 16, 128-137.

Johnson, David Kyle (2014). Hypothesis as a Solution to the Problem of No Best World. Sophia. Published online: http://link.springer.com/article/10.1007\%2Fs11841-013-0397-6\%23page-1.

Johnson, David Kyle (2012). The Failure of Plantinga's Solution to the Logical Problem of Natural Evil. Philo 15(2), 145-157. Available at: http://staff.kings.edu/davidjohnson/The $\% 20$ Failure $\% 20$ of $\% 20$ Plantinga's $\%$ 20 solution $\% 20$ to $\% 20$ the $\% 20$ Logical $\% 20$ Problem $\% 20$ of $\% 20$ Natural $\% 20$ Evi $\% 20$ v $1.6 .1 \%$ 20(Corrections\%20applied).pdf.

Kraay, K. J. (2010). Theism, possible worlds, and the multiverse. Philosophical Studies, 147, 355-368.

Malm, H. (1995). Liberalism, bad samaritan law, and legal paternalism. Ethics, 106(1), 4-31.

McHarry, J. D. (1978). A theodicy. Analysis, 38, 132-134.

Monton, B. (2010). Against multiverse theodicies. Philosophy, 13(2), 113-135.

Rowe, W. (2007). William L. Rowe on philosophy of religion: Selected writings. Hampshire England and Burlington VT: Ashgate Publishing.

Rowe, W. (2004). Can god be free? New York and Oxford: Oxford University Press.

Singer, P. (1972). Famine, affluence and morality. Philosophy and Public Affairs, 1(1), 229-243.

Silver, J. (1985). The duty to rescue: a reexamination and proposal. William \& Mary Law Review, 26(3), 423-448.

Turner, D. (2003). The many-universes solution to the problem of evil. In Gale \& Pruss (Eds.), The existence of god (pp. 143-159). Aldershot: Ashgate.

van Inwagen, P. (2006). The problem of evil. New York and Oxford: Oxford University Press.

Wykstra, S. (1984). The humean obstacle to evidential arguments from suffering: On avoiding the evils of appearance. International Journal for Philosophy of Religion 16, 73-94. Cited by Alston, William P. 1996. The inductive argument from evil and the human cognitive condition. In H.-S. Daniel (Ed.), The evidential argument from evil (pp. 97-125). Bloomington and Indianapolis: Indiana University Press. 102. 